\title{
Providing Perpetual Access
}

\section{Results of a Survey}

\section{Sarah Glasser}

This paper presents the results of an online survey about perpetual access for electronic serials that have been canceled, have ceased, or have transferred to different publishers. The survey sought to ascertain the true experiences of libraries working to maintain perpetual access. Results indicate a high success rate for providing perpetual access. Results also indicate a lack of standardization for and many challenges to keeping track of and providing perpetual access. A discussion section expands on key findings and the most common obstacles to providing perpetual access.

uch has been written in the library literature about the move from print 1 to electronic serials, the debate over access versus ownership, and the perpetual access clauses of various content providers. However, there is little information in the literature that explores the actual attempts made by libraries to invoke perpetual access. Significant moves from print to electronic serials, the discarding of print serial holdings and, more recently, large cancelation projects, including Big Deal cancelations, bring this issue to a head. This paper presents the results of an online survey that sought to uncover the true experiences of libraries working to provide and maintain perpetual access to electronic serials that have been canceled, have ceased, or have transferred to different publishers. Questions cover the conditions under which libraries pursue perpetual access, the varying reasons for success or lack of success, and the cost, both monetary and labor-based, of providing such access. A discussion section expands on key findings and the most common obstacles to providing perpetual access. For the purpose of this paper, perpetual access is defined as access to the years of content paid before the affected serials were canceled, ceased publication, or transferred to different publishers.

Sarah Glasser (sarah.glasser@hofstra.edu) is Serials/Electronic Resources Librarian at Hofstra University, Hempstead, New York.

Manuscript submitted January 15, 2014; tentatively accepted March 20, 2014 pending minor revisions; revised manuscript submitted April 7, 2014; accepted for publication April 11, 2014.

\section{Literature Review}

Several people have documented the vagueness in the language of perpetual access clauses in publisher licenses for electronic journals (e-journals). ${ }^{1}$ Beh and Smith analyzed the perpetual access clauses of nineteen of their libraries' e-journal licenses and found the wording so convoluted, they did not know to 
what they were entitled. ${ }^{2}$ Stemper and Barribeau analyzed the perpetual access clauses of forty of their libraries' e-journals licenses and found that while most of the publishers offer some form of perpetual access, it is not always clear what it entails. ${ }^{3}$ They provide examples of language vagueness, such as using "reasonable efforts" and "discuss[ing] a mechanism" for providing perpetual access. ${ }^{4}$ Wolf outlines situations where perpetual access is offered, but in an unusable format, such as a nonsearchable DVD or raw data that requires server space, a search interface, and a way to limit use to library patrons. He advocates working with publishers "to provide reasonable standards and expectations for perpetual access."

This vagueness in the language of perpetual access license clauses has caused skepticism regarding publishers' ability to provide perpetual access. A survey by Watson found that some librarians "did not trust e-journal providers to continue archival access, even if it were guaranteed in a license agreement." Similarly, Beh and Smith voice "profound concerns regarding the library's ability ... to provide meaningful perpetual access to previously subscribed content to its users. "7 Carr writes that even when perpetual access provisions do exist, the "means of carrying out these provisions are oftentimes insufficiently developed." Finally, Watson worries that "loss of archival access seems inevitable."

The extensive work required by libraries to provide perpetual access for e-journals has also been documented in the library literature. Bascones outlines record-keeping shortfalls and how complicated and time-consuming it can be to confirm perpetual access entitlements. ${ }^{10}$ She notes that some libraries found it was not worth the time and effort. ${ }^{11}$ Watson found that some libraries did not want the extra work associated with using formats such as CD-ROMs for archival access. ${ }^{12}$ The added complexity of journal titles that transfer to different publishers is noted by Beh and Smith, Stemper and Barribeau, and Watson. ${ }^{13}$

Nothing was found in the literature that documents the actual experiences of libraries attempting to provide perpetual access to e-journal content that has been canceled, ceased, or transferred to different publishers. Beh and Smith note that their library has not yet had the opportunity to test perpetual access for more than a few transferred titles. ${ }^{14}$ Similarly, Watson found that many of her survey respondents had not canceled enough e-journals to report on perpetual access success rates. ${ }^{15}$

\section{Survey Results}

The perpetual access survey was created using the Qualtrics survey software (http://qualtrics.com) and a link to it was posted to the ERIL-L, LIBLICENSE-L, and SERIALST discussion lists. The survey remained open for six weeks, from August 6 through September 17, 2013. Two hundred responses were received. A copy of the survey is in the appendix.

The majority of survey respondents (74 percent) work at a university. None of those who completed the survey work at a community college, 12 percent works at a fouryear college, and the remaining respondents (14 percent) work at other types of institutions, such as medical libraries, law libraries, government institutions, and nongovernmental research institutes.

The respondent institutions' FTE (full-time equivalent) student body varied from 2,500 or fewer (16 percent) to $30,001-45,000$ (9 percent), with most institutions having a student FTE in the 2,501-10,000 range (26 percent), the $10,001-20,000$ range (24 percent), and the $20,001-30,000$ range (26 percent). Sixty percent of the respondents worked at institutions with a serials budget of $\$ 1$ million or more. Many respondents were unsure as to what percentage of the serials collection in their library is electronic. Of those who provided a percentage, 60 percent said that 80 percent or more of their serials collection is electronic.

The first survey question addressed the situations in which the respondents' libraries had the opportunity to invoke and thus test perpetual access provisions for electronic serials. Multiple answers were permitted, and respondents were asked to check all that applied. Eighty percent replied that they invoked perpetual access for individual canceled titles, 62 percent for transferred titles, 60 percent for ceased titles, and 26 percent for full Big Deal e-journal packages that had been canceled (see figure 1). A small percentage (6 percent) indicated "other" and included situations such as small canceled packages (e.g., society packages) and when a company was acquired by another.

The next few questions focused on the main survey objective and asked how often respondents' libraries were able to successfully provide perpetual access, in what form the perpetual access was provided when successful, and the reasons for unsuccessful attempts. Somewhat surprisingly, 92 percent of survey respondents indicated that their libraries were successfully able to provide perpetual access always (13 percent), often (39 percent), or sometimes (40 percent). If the "sometimes" responses are removed, the number still exceeds 50 percent (52 percent). Only 2 percent answered that their library was never successful, and 6 percent indicated rarely (see figure 2).

Of the respondents who indicated that their libraries were able to successfully provide perpetual access to their users, 87 percent did so by continuing to link to the publisher's website; 56 percent provided access by linking to a membership archive such as LOCKSS, CLOCKSS, or Portico; 14 percent referred users to CD-ROMs, DVDs, or external drives that can be accessed on request; and 9 percent linked to content stored on a library server (see figure 


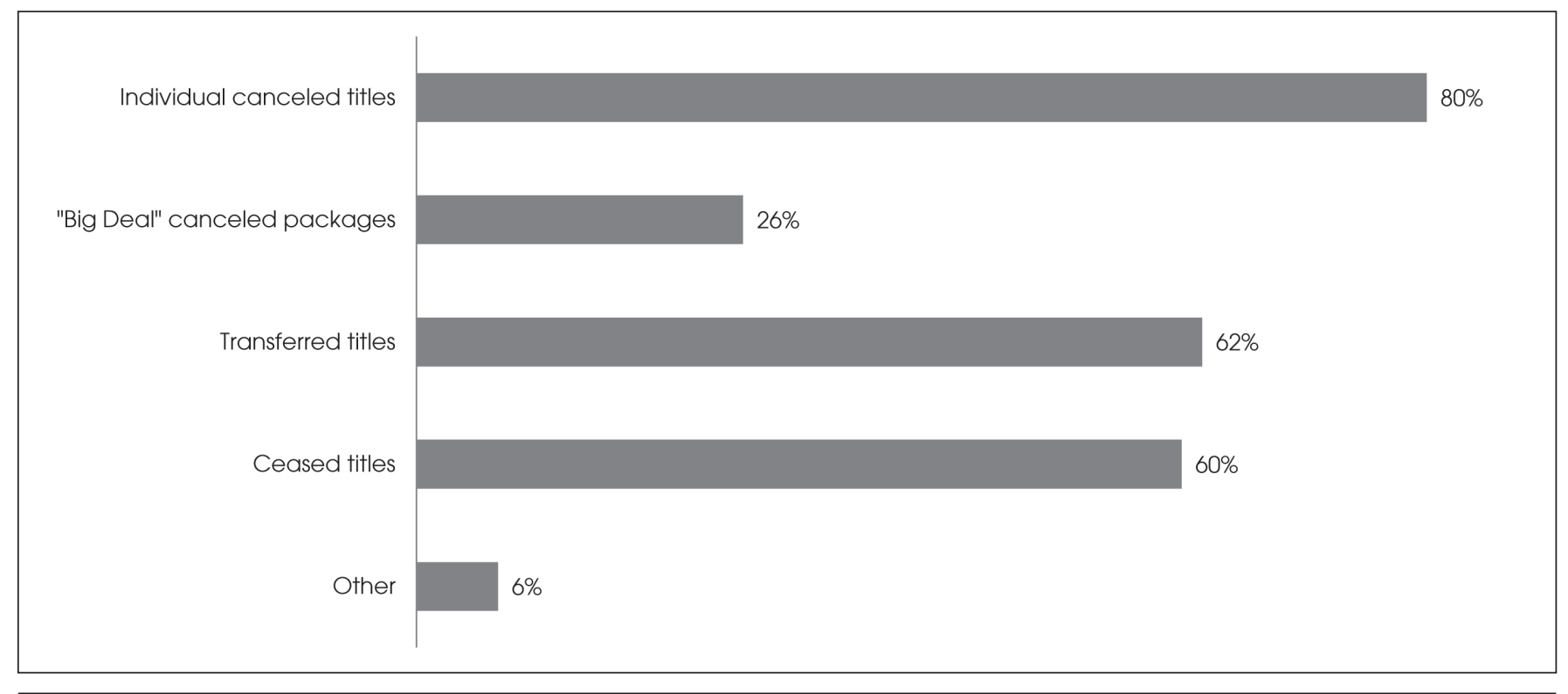

Figure 1. Survey responses to the question "In What Situations Has Your Library Had the Opportunity to Invoke and Thus Test Perpetual Access Provisions for Electronic Serials?"

3). Another 7 percent selected "other" and specified details such as using EBSCO's Electronic Journals Service (EJS), linking to content stored on a consortium server, or linking to an institutional repository for local materials. Comments that accompanied responses to this question expose a preference for linking to the publisher or provider's website. One respondent expressed that this preference over linking to an archive such as LOCKSS, CLOCKSS, or Portico was due to the ability to use the library's link resolver. ${ }^{16}$ Another respondent mentioned only providing perpetual access if available via the publisher or provider's website. Two respondents commented that their libraries have CDROMs and hard drives but do not currently make them accessible to users, and one said his library would accept CD-ROMs if there is no other option. Two respondents relayed experiences of successful perpetual access only after logging significant and time-consuming complaints to the publisher.

Regarding reasons for unsuccessful attempts, more than half of the respondents ( 51 percent) indicated that they were unable to provide perpetual access to users because the publisher offered perpetual access in an unworkable form, such as CD-ROMs, external hard drives, DVDs, raw data that would have to be hosted on the institution's own server, and emails with PDF attachments (see figure 4). This high number indicates that while some libraries are providing perpetual access to users via CD-ROMs and other external data (14 percent, see above), such an arrangement is unworkable and unacceptable for many other libraries. The following comment from a survey respondent sums up the issue:
We have stacks of DVDs, CDs, etc. whose content cannot be uploaded to a searchable platform, which users would want. We have one computer that stores all the PDF downloads . . . but those are not "discoverable" by anyone-staff included. I have PDFs of issues that were emailed to my address as the journal admin. We have ancient mag tape and floppy discs that can no longer be read. We may as well not have this content at all, as we have no way of serving it and making it searchable or linkable. We cannot put paid content in our institutional repository because we have no way to keep noninstitutional users out. We could possibly process the $[$ sic $]$ circulate a CD or DVD, but if it is not returned, an entire journal archive is lost. And ... of course, we don't have the staff to process this material anyway. ${ }^{17}$

As the above comment notes, staff needs are also an issue. Indeed, 45 percent of survey respondents indicated that lack of staff at their institutions was a reason for unsuccessful perpetual access attempts (see figure 4). The other reasons were lack of funds for the fee required for continued access ( 26 percent), and "other" (36 percent). The most common reasons specified for "other" were lack of documentation proving payment for the years in question, claim denials following title transfers (new publisher did not honor former publisher's agreement), lack of license, and that the usage of some titles was not worth the perpetual access fee. Comments following this question confirmed 


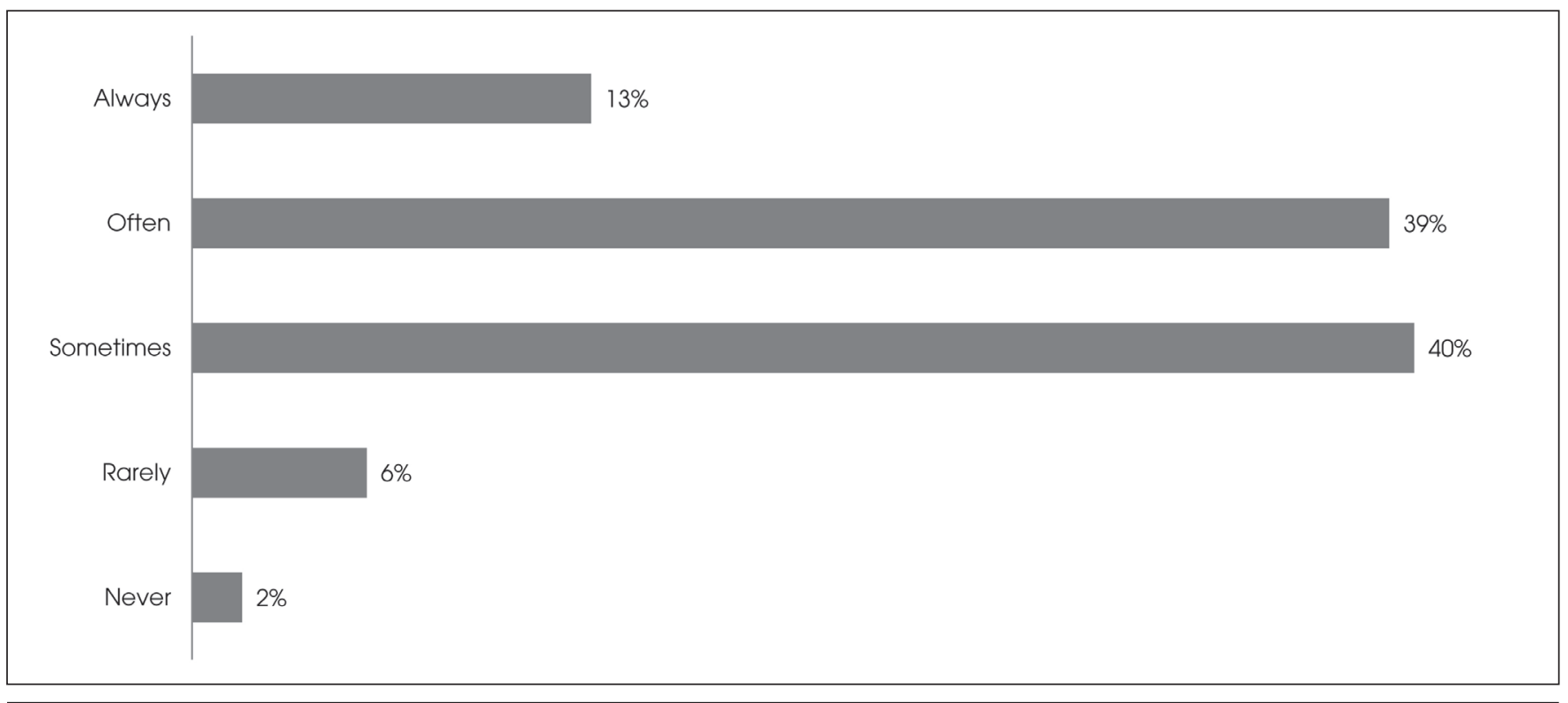

Figure 2. Survey responses to the question "How Often Has Your Library Been Able to Successfully Provide Perpetual Access?"

that missing payment documentation, particularly for payments more than five years old, and titles that transferred to new publishers with different policies are common obstacles to providing perpetual access. Other comments disclosed a frustration with the vagueness of license agreements and a declaration of the extensive work required to provide and maintain perpetual access to e-journals.

Considering the comments regarding the extensive work required to provide and maintain perpetual access, it is not surprising that 63 percent of respondents indicated that this responsibility falls to a professional librarian. Twenty percent indicated that support staff are responsible; not one respondent indicated that a student is responsible for this work. However, 18 percent chose "other," almost all of whom specified that setting up and maintaining perpetual access is a team effort, involving librarians, support staff, and in some cases systems or information technology (IT) personnel.

In addition to labor costs, 15 percent of respondents reported that their library pays a monetary fee for perpetual access, and 46 percent answered that their library pays a fee in some cases. Only 39 percent of respondents answered that their library does not pay a fee. Comments indicate that in many cases, the library pays no fee as long as it still holds some subscriptions with the publisher or vendor. Some commented that a hosting fee is paid if justified by usage. One respondent wrote that if a fee were specifically mentioned in the license, the library would pay it. However, there were also several comments on membership fees paid for Portico or costs for the purchase of legacy collections. This was not the intent of the question, and this misunderstanding may have skewed the results. For this reason, the responses to this question are of limited value.

The remaining survey questions were open-ended. One asked respondents what they thought was the most challenging part of providing perpetual access. Four areas emerged as particularly challenging issues affecting the success of perpetual access: the work involved, documentation, dealing with transferred titles, and license issues.

Most often mentioned was the extensive work involved, specifically determining eligibility, setting up linking, checking and rechecking access (several mentioned that access periodically disappears), claiming lost access, and dealing with files like CD-ROMs and archiving issues. Documentation was the next most often mentioned challenge, with many acknowledging shortfalls in record keeping and the difficulties of tracking down payment history, determining which titles are core or "subscribed" titles (often with Big Deals only the core, initially subscribed titles are eligible for perpetual access), and knowing when perpetual access eligibility began. One survey respondent portrays the issue well in this comment:

For journals, it's keeping up with when your perpetual access officially begins. Our record-keeping practices have varied so widely over the years that in many cases, it's nearly impossible to determine when we officially added e-access to our subscriptions, and I'm loathe to just take the publishers at their words-I doubt their records are that much better than ours. ${ }^{18}$ 


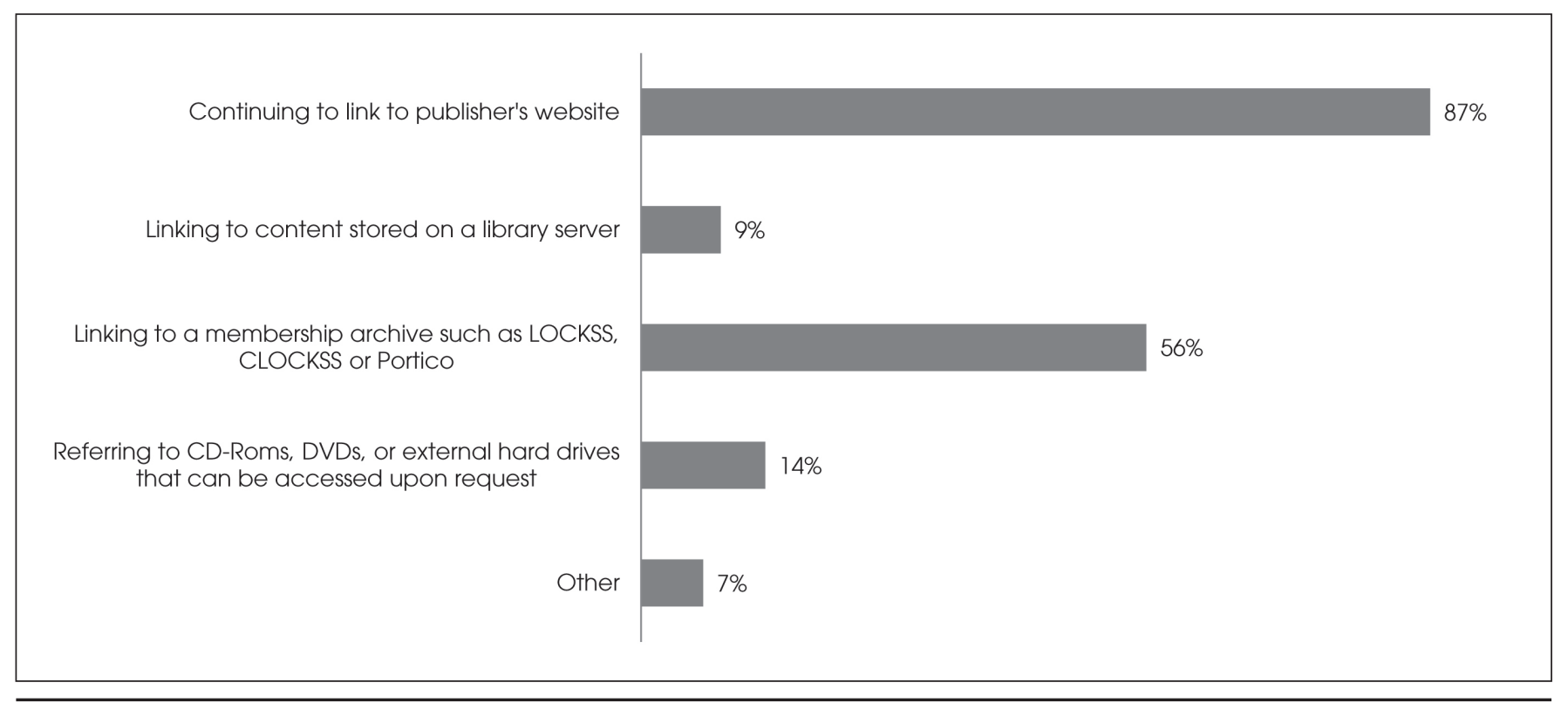

Figure 3. Survey responses to the question "When Providing Perpetual Access is Successful, How is it Provided?"

Dealing with titles that transfer to a different publisher was the third most mentioned challenge and a clear source of frustration and time-consuming efforts. Several comments referred to situations where perpetual access was lost because the new publisher did not honor the former publisher's agreement. Even when perpetual access is not lost, keeping track of where the perpetual access is hosted for transferred titles (new publisher, former publisher, vendor platform) is a formidable task that requires staff time that many libraries simply do not have.

The final issue most often mentioned as a challenge to providing perpetual access relates to licenses. A specific area of difficulty is the vagueness of license wording. Such vagueness leaves libraries unsure about the extent and format of the perpetual access available to them should titles cease or be canceled. Other challenges concern outdated licenses that were signed before libraries began insisting on perpetual access language, publishers that do not offer any type of perpetual access, and smaller publishers that do not use licenses.

The survey concluded with an open-ended question allowing for any additional comments from respondents. Comments were generally positive, with two respondents explicitly stating that they have experienced few problems regarding perpetual access. Numerous comments touched on the importance of perpetual access provisions in licenses, and several explicitly mentioned that they do not move subscriptions to electronic-only unless perpetual access is offered. One respondent from a European institute mentioned difficulties with non US/UK publishers that are unfamiliar with perpetual access and smaller publishers that are unable or unwilling to offer perpetual access guarantees. And lastly, one comment mentioned the major role consortia can play in facilitating perpetual access from both a licensing and a technical standpoint.

\section{Discussion}

The survey results indicate a high success rate for providing perpetual access to electronic serials (92 percent of survey respondents indicated that their libraries were successfully able to provide perpetual access always, often, or sometimes). However, results also indicate a lack of standardization for and many challenges to keeping track of and providing perpetual access. While the state of perpetual access does not seem as dire as Beh and Smith and Watson feared, the sheer amount of work involved, record keeping shortfalls, the vagueness of license agreements, the wide range of ways in which perpetual access can be (and is) offered, and the uncertain nature of transferred titles all limit the success of providing perpetual access to users.

Improved record keeping and more standardized perpetual access clauses in licenses could alleviate some of these challenges. Bascones reports on an effort in the United Kingdom to create a Post-Cancellation Entitlement Registry that would provide authoritative records on the perpetual access rights for UK higher education institutions. ${ }^{19}$ Such a registry, if successfully created and maintained, could save a lot of time, provide definitive information on perpetual access entitlements, and ultimately improve access. However, success of such an initiative relies on the involvement 


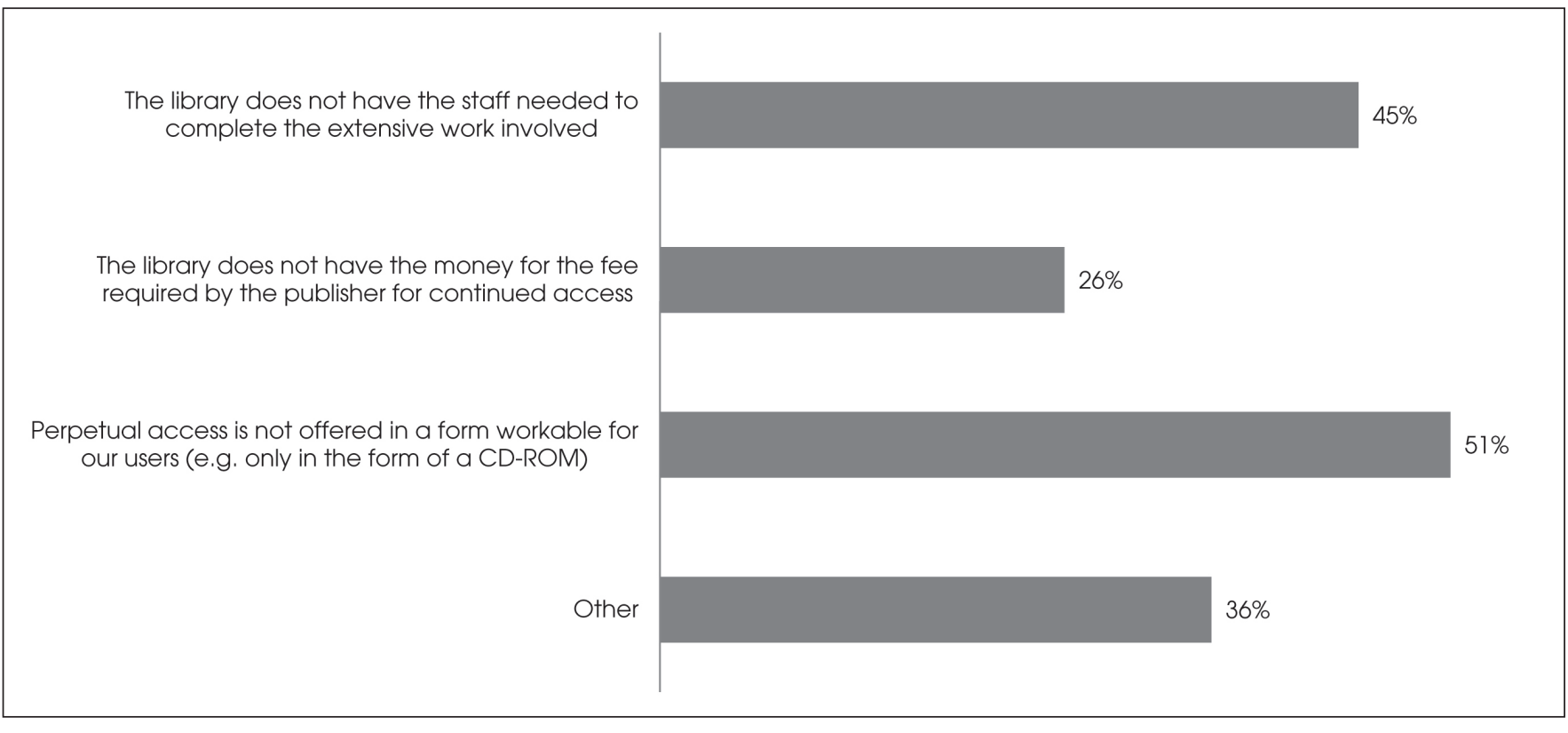

Figure 4. Survey responses to the question "When Providing Perpetual Access is Unsuccessful, What are the Reasons?"

of all stakeholders and a commitment to better record keeping. Furthermore, this project is specific to higher education institutions in the United Kingdom.

Standardization of the perpetual access clauses in license requirements is probably the most difficult obstacle to overcome. While many libraries show a commitment to perpetual access by insisting that it is offered before switching journal subscriptions from print to electronic, it is not always possible for publishers to be as specific as libraries would like. Until publishers can be more specific, problems with language vagueness in perpetual access license clauses will continue. The National Information Standards Organization (NISO) sponsors two license-related initiatives, but neither requires specific perpetual access language, nor can either require publishers to offer perpetual access in any particular form. The two initiatives are ONIX for Publications Licenses (ONIX-PL) and Shared Electronic Resources Understanding (SERU). ONIX-PL, a joint initiative between EDItEUR and NISO, is an XML schema that, together with a dictionary of controlled vocabulary for license terms, makes licenses machine-readable, thereby enabling license information to be ingested into library electronic resource management systems (ERMS) ${ }^{20}$ It is a way to map the information from the license document to fields in a library's ERMS. This helps libraries to manage their electronic resources and can help with perpetual access documentation, but it only maps the information that is in the license signed by both parties. It does not mandate or suggest any specific requirements. SERU is an alternative to the complexity of licenses. If both the library and the publisher agree to adhere to the SERU guidelines, as outlined in the NISO SERU Recommended Practice, SERU can be used in lieu of a license. ${ }^{21}$ The SERU guidelines include a section stating that perpetual access will be provided, but it does not specify how. ${ }^{22}$ In sum, while these two initiatives support perpetual access, they cannot solve the problem of vagueness in perpetual access license clauses. Publishers, libraries, and other stakeholders must continue to work together to agree on terms acceptable to all parties.

It is not surprising that perpetual access offered in unworkable, often unsearchable, forms such as CD-ROMs is a significant obstacle to the success of providing perpetual access (51 percent indicated this as a reason for failed attempts). With link resolvers and discovery systems fueling much of the discovery of and access to electronic content, housing content outside of this structure simply does not work well. Not only does it require extra work on the part of library staff, but it also requires users to come to the library for access, defeating much of the original purpose of moving from print to electronic format. In many cases, perpetual access offered on CD-ROMs, as PDFs, or in other external hardware formats is equivalent to no perpetual access at all.

Of all the forms in which perpetual access can be offered, survey results show a preference for access through the publisher or provider's website. This allows for continued linking through the link resolver, retains the look and functionality to which users are accustomed, and is easily incorporated into current workflows. While LOCKSS, CLOCKSS, and Portico can be linked through link resolvers, it requires additional set up and changes the look of access 
for users. Additionally, these archiving initiatives have membership fees and are limited to the content of participating publishers. In their joint report on LOCKSS and other preservation initiatives, 2CUL (Cornell University and Columbia University) found that only a relatively small percentage of their e-journal holdings were preserved in LOCKSS and Portico. ${ }^{23}$ They also note that the titles preserved in LOCKSS and Portico are almost exclusively limited to those with an ISSN or an e-ISSN. CLOCKSS is a so-called "dark archive" that requires a "trigger event" for access; cancelation or transfer of a title does not meet the requirement for such an event. ${ }^{24}$ Portico also requires a trigger event but offers a separate "post-cancellation access" (PCA) option. ${ }^{25}$ The PCA option is only available if the publisher agrees to it. At the time of the writing of this paper, 147 (77 percent) of the 190 e-journal publishers that participate in Portico allowed their content to be accessed for PCA ${ }^{26}$ Even when PCA is allowed through Portico, libraries still need to show proof that they paid for subscriptions for the years in question, which, as noted above, can be problematic. Libraries also need to maintain their Portico subscriptions to continue PCA through Portico. LOCKSS can be used for perpetual access, but requires staff time to set up and maintain. When the 2CUL report was issued (October 2011), neither Cornell University nor Columbia University were making content from LOCKSS available to their users; instead, they were using it as a dark archive. ${ }^{27}$ In sum, while these three initiatives all provide an important preservation service, and two of the three can provide perpetual access to many titles, they are not a comprehensive solution for libraries hoping to provide perpetual access for e-journals that have been canceled, have ceased, or have transferred to different publishers.

And finally, transferred titles clearly represent a challenge when it comes to providing perpetual access. This was mentioned in both the comments regarding unsuccessful perpetual access attempts and the comments on the most challenging part of providing perpetual access. Despite the existence of the TRANSFER Code of Practice, a standard created by the United Kingdom Serials Group (UKSG), perpetual access to transferred titles is often lost. As Watson states, "Even when vendors do promise archival access, they cannot guarantee continued access when a journal changes publisher or a publisher changes its relationship with a third party vendor."28 Beh and Smith similarly note that "despite the clause in the contract, perpetual access is guaranteed only when the title remains with the original publisher." ${ }^{\prime 2}$ However, there is hope that this will change. The latest version of the Transfer Code of Practice (Version 3.0) includes a new section on licensing terms with the following language: "The receiving publisher will ensure that any content that has been previously published under license without charge to users will continue to be made available under the existing terms. ${ }^{30}$ This has the potential to greatly increase the success rate of providing perpetual access when titles transfer to new publishers.

\section{Conclusion}

This paper reports on a survey that sought to provide a deeper understanding of the extent to which libraries are pursing perpetual access and the outcomes of such attempts for electronic serials that have been canceled, have ceased, or have transferred to different publishers. Results indicate a high level of success and a preference for such access by continuing to link to the publisher or provider's website. The four top challenges to providing perpetual access are the extensive work involved, documentation shortfalls, dealing with transferred titles, and license issues. In some cases, the library simply lacked the staff to complete the work required to provide perpetual access (determining if the library is eligible for perpetual access, contacting the publisher to find out how perpetual access will be provided, verifying access, updating the link resolver, updating the bibliographic record, etc.). Clear, consistent licensing language for perpetual access clauses would help. Better documentation for records more than five years old would also help. No longer accepting nonintegrated forms of perpetual access such as CD-ROMs could increase the success rate of perpetual access. Archiving initiatives such as LOCKSS, CLOCKSS, and Portico are important, but are currently not comprehensive enough, and in the case of CLOCKSS and sometimes Portico, are not able to offer perpetual access when subscriptions are canceled. Transferred titles have always caused librarians extra work and perpetual access is no exception. However, the newest version of the UKSG Transfer Code of Practice could bring improvement with an additional section requiring the transfer publisher to honor the perpetual access entitlements of the former publisher.

The state of perpetual access is not as bad as many have feared. Hopefully, with more awareness, improved transfer policy, more diligent record keeping, and more standardized license language, things will improve.

\section{References and Notes}

1. Although the survey uses the term "electronic serials," many of the respondents as well as many of the articles cited in the literature review use "e-journals." For this reason, both terms are found in the article; their meaning is interchangeable.

2. Eugenia Beh and Jane Smith, "Preserving the Scholarly Collection: An Examination of the Perpetual Access Clauses in the Texas A\&M University Libraries' Major E-Journal Licenses," Serials Review 38, no. 4 (December 2012): 235-42.

3. Jim Stemper and Susan Barribeau, "Perpetual Access to Electronic Journals: A Survey of One Academic Research 
Library's Licenses," Library Resources \& Technical Services 50, no. 2 (April 2006): 91-109.

4. Ibid., 102.

5. Robert Wolf, "Budget Crisis: A Review of Perpetual Access," North Carolina Libraries 67, no. 1-2 (2009): 34, accessed November 27, 2013, www.ncl.ecu.edu/index.php/NCL/article/viewFile/280/315.

6. Jennifer Watson, "You Get What You Pay For? Archival Access to Electronic Journals," Serials Review 31, no. 3 (2005): 203.

7. Beh and Smith, "Preserving the Scholarly Collection," 242.

8. Patrick L. Carr, "The Commitment to Securing Perpetual Journal Access: A Survey of Academic Research Libraries," Library Resources \& Technical Services 55, no. 1 (January 2011): 5 .

9. Watson, "You Get What You Pay for?" 204.

10. Magaly Bascones, "JISC Collections: Post-Cancellation Entitlement Registry Scoping Project," Collaborative Librarianship 4, no. 3 (2012): 85-95. Bascones uses the term "post-cancellation," but for consistency, this paper will use "perpetual access."

11. Bascones, "JISC Collections," 92.

12. Watson, "You Get What You Pay for?" 203.

13. Beh and Smith, "Preserving the Scholarly Collection"; Stemper and Barribeau, "Perpetual Access to Electronic Journals"; Watson, "You Get What You Pay for?"

14. Beh and Smith, "Preserving the Scholarly Collection," 239.

15. Watson, "You Get What You Pay for?" 203.

16. Currently, it is possible to link CLOCKSS, LOCKSS, and Portico content through many link resolvers.

17. Comment section following Question 3, from author's Perpetual Access Survey.
18. Response to question 7 from author's Perpetual Access Survey (see appendix).

19. Bascones, "JISC Collections."

20. “ONIX-PL," EDItEUR, accessed December 23, 2013, www .editeur.org/21/ONIX-PL.

21. National Information Standards Organization, "SERU Recommended Practice (RP-7-2012)," accessed December 23, 2013, www.niso.org/publications/rp/RP-7-2012_SERU.pdf.

22. Ibid., 5 .

23. Cornell University Library and Columbia University Library, "Final Report of the 2CUL LOCKSS Assessment Team," October 2011, accessed December 13, 2013, http://2cul.org/ sites/default/files/2CULLOCKSSFinalReport.pdf.

24. "CLOCKSS: A Trusted Community-Governed Archive," CLOCKSS, accessed December 16, 2013, www.clockss.org/ clockss/Home.

25. "E-Journal Preservation Service," Portico, accessed December 16, 2013, www.portico.org/digital-preservation/services/ejournal-preservation-service.

26. "Who Participates in Portico? Publishers," Portico, accessed December 16, 2013, www.portico.org/digital-preservation/ who-participates-in-portico/participating-publishers.

27. Cornell University Library and Columbia University Library, "Final Report of the 2CUL LOCKSS," 3.

28. Watson, "You Get What You Pay for?" 203.

29. Beh and Smith, "Preserving the Scholarly Collection," 242.

30. United Kingdom Serials Group (UKSG), "Transfer Code of Practice: Version 3.0" (consultation draft), 5, accessed November 27, 2013, www.uksg.org/sites/uksg.org/files/ TRANSFER_Code_of_Practice_CONSULTATION\%20 DRAFT_V3.0.pdf.

\section{Appendix: Perpetual Access Survey}

This survey seeks to ascertain the extent to which perpetual access is being pursued and provided for electronic serial titles that have been canceled, have ceased, or have transferred to different publishers. If you work at a library that has had the opportunity to test perpetual access provisions - whether successful or not-your participation would be very much appreciated. All answers will be kept confidential. Thank you in advance for your participation.

1. In what situations has your library had the opportunity to invoke and thus test perpetual access provisions for electronic serials? Check all that apply.

- For individual canceled titles

○ For entire "Big Deal" e-journal packages that have been canceled

- For transferred titles

- For ceased titles

$\circ$ Other, please specify:
2. How often has your library been able to successfully provide perpetual access?

o Never

$\circ$ Rarely

o Sometimes

- Often

$\circ$ Always

If Always Is selected, skip to question 4. 
3. When providing perpetual access is unsuccessful, what are the reasons? Check all that apply (section for additional comments is below).

- The library does not have the staff needed to complete the extensive work involved.

- The library does not have the money for the fee required by the publisher for continued access.

- Perpetual access is not offered in a form workable for our users (e.g. only in the form of a CD-Rom). Please specify:

$\circ$ Other reason(s), please specify:

Comments:

4. When providing perpetual access is successful, how is it provided? Check all that apply (section for additional comments is below).

Skip this question if "Never" is selected in question 2.

- By continuing to link to publisher's website

- By linking to content stored on a library server.

- By linking to a membership archive such as LOCKSS, CLOCKSS or Portico

- By referring to CD-Roms, DVDs, or external hard drives that can be accessed upon request

○ Other, please specify:

Comments:

5. Who is responsible for setting up and maintaining perpetual access at your library?

o Librarian

- Support staff

- Student

- Other, please specify:

6. Does your library pay a fee to the publisher for perpetual access?

$\circ$ Yes

○ No

- In some cases. Please elaborate:

○ Don't know
7. What would you say is the most challenging part of providing perpetual access?

8. At what type of institution do you work?

$\circ$ Community college

○ 4-year college

$\circ$ University

○ Other, please specify:

9. What is the approximate size of your institution's student body in FTEs (full-timee quivalent)?

○ 2,500 or less

○ $2,501-10,000$

○ $10,001-20,000$

○ 20,001-30,000

○ 30,001-45,000

○ more than 45,000

10. Approximately what is your library's total annual budget (USD) for serials_-including both electronic and print?

$\circ$ under $\$ 50,000$

○ $\$ 50,000-\$ 99,999$

○ $\$ 100,000-\$ 249,000$

○ $\$ 250,000-\$ 499,999$

○ $\$ 500,000-\$ 999,999$

○ $\$ 1$ million or more

○ Don't know

11. Approximately what percentage of your serials collection is electronic?

12. Any additional comments? Please add below.

Thank you for your participation! 